\title{
Premises of Inclusive Access and Success of Roma People in the Romanian Higher Education
}

\author{
Diana-Maria Cismaru, Cristina Fiț and Delia Gologan
}

\section{National Context}

The data used in this article derive from an impact study regarding the equity policy already put in place by the Romanian national institutions, in order to evaluate their real impact and the level of reaching their pre-set objectives. The study is part of the project coordinated by UEFISCDI and co-funded by the European Structural Funds (POSDRU) entitled "Internationalization, equity and university management for a more qualitative Higher Education system" (IEMU). The main objective of the project is to raise the quality of the Romanian Higher Education system by developing the public policies in the international and equity dimensions of education, as well as the management level for Higher Education Institutions (HEIs).

This first part of the article provides a national overview of the Roma population status, in terms of history, living conditions, forms of discrimination, as well as the specific positive measures undertaken by the Romanian Government or other public authorities aiming to improve their situation. All these constitute the framework for discussing the study findings and the impact of the public policies that were implemented so far.

\footnotetext{
D.-M. Cismaru ( $ه)$

National University of Political Studies and Public Administration,

Bucharest, Romania

e-mail: diana.cismaru@comunicare.ro

C. Fiţ · D. Gologan

Executive Agency for Higher Education, Research, Development and Innovation

Funding (UEFISCDI), Bucharest, Romania

e-mail: cristina.fit@uefiscdi.ro

D. Gologan

e-mail: delia.gologan@uefiscdi.ro

(C) The Author(s) 2015
}

A. Curaj et al. (eds.), The European Higher Education Area,

DOI 10.1007/978-3-319-20877-0_33 


\subsection{Roma People in Statistics}

Roma people are an officially recognized ethnic minority in Romania. According to the population census of 2002 almost $2.5 \%$ of Romania's population $(535,140$ people) is Roma; by 2011 this was estimated to have increased to approximatively $3.2 \% .^{1}$ This data however cover only to the citizens with an official ID declaring their ethnicity. Official data do not reveal the actual size of Roma population, since it is not mandatory to declare one's ethnicity. According to the EU Communication "An EU framework for national Roma integration strategies up to 2020" and based on the European Council data, the European Commission estimated the Roma population at $8.32 \%$ from Romania's overall population.

The Roma people are of Indian origin and they arrived in Romania during the 14th century as slaves and treated ever since as having an inferior social status. They were granted freedom and the right to become land owners in 1864; however, they kept their nomadic characteristic, rarely settling down in fixed abodes. During World War II many of them were deported, but this oppression stopped during the communist period when, for the first time, they were allowed to hold jobs in the industry and the army. The long period of their marginalization is now visible and reflects in their poor living conditions. In 1997, $79 \%$ of Roma were facing severe poverty, $44 \%$ of Roma men and $59 \%$ of Roma women were illiterate, while $9 \%$ of them possessed neither an ID, nor a birth certificate. ${ }^{2}$

The general situation of Roma people is characterized by a low socio-economic status, poor living conditions, low levels of professional qualifications and a high level of unemployment. Only $53 \%$ of Roma men and $23 \%$ of Roma women are paid for their work in the formal economy, but about one third receive daily wages in the informal sector (also know as "the black market"). Thus, practically one third of Roma workers do not have a steady work place and revenue, due in part to low educational qualifications (Preda 2009, p. 228). Many Roma people live in insalubrious conditions, without access to running water or electricity: $15 \%$ of Roma people do not have electricity in their households, compared with only $2 \%$ of the rest of the Romanian population (idem).

According to official statistics, the counties with the greatest percentages of self-declared Roma people are: Mureș (7.0 \%), Călărași (5.6 \%), Bihor (5.0), Dolj (4.3\%), Sibiu (4.2\%) and Arad (3.9\%) (Bennett 2010, p. 2).

During the negotiation period preceding the adhesion of Romania to the EU, the Roma attracted the attention of European institutions due to the prospect of mass emigration into other EU states under the free movement of labour at European

\footnotetext{
${ }^{1}$ Data regarding the evolution of the ethnic communities are available online, in Romanian, at the following link: http://www.incont.ro/infografice/evolutia-comunitatilor-etnice-in-romania-judetulunde-sunt-cei-mai-putini-romani-12-6-din-populatia-totala.html; last accessed: September 2014.

${ }^{2}$ Document available online in Romanian, full-version at the following link: http://www.edrc.ro/ docs/docs/etnomobilitate/Intregul_volum.pdf; last accessed: September 2014.
} 
level. As a result, these institutions began to pressure the Romanian Government to take action on the Roma situation. Therefore, in 1998 the National Office for Roma was founded and it started working on the first strategy addressing the needs of Roma people.

\subsection{Discrimination of Roma People in Society and the Educational Environment}

The status quo for Roma is difficult to change, largely because of the attitudes which other Romanians have towards them. In a study from 2005, $35.8 \%$ of Romanians preferred that the Roma people should live isolated from the society, $65.8 \%$ were against allowing them to go abroad and $47.3 \%$ agreed with limiting their rights to reproduction (Andreescu 2005, pp. 81-82). Also, according to a 2009 study performed in seven recent EU countries (EU Agency for Fundamental Rights 2009, p. 3), Roma people are the most often subjects of discrimination (81\% were victims of assault, threat or serious harassment in the previous year of study). Stereotypes about Roma include such things as an alleged proclivity towards crime and violence, as well as a lack of interest in school for their young. $72 \%$ of respondents in the above mentioned study believed that Roma people habitually broke the law, and $20 \%$ would forbid access of Roma to stores and restaurants. Although $34 \%$ of respondents had no interaction with Roma people in the last six months, $64 \%$ considered Roma people more violent than the rest of the population. $23 \%$ of respondents associated the word Roma with "theft", "burglary" and "begging", while $10 \%$ associated them with "filth" or "lack of education". Only $16 \%$ of respondents considered Roma people as being normal people (EU Agency for Fundamental Rights 2009, p. 2 after Bennett 2010). Moreover, $40 \%$ of Romanians disapprove of mixed marriages between Romas and Romanians, and $25 \%$ think that Roma children should not play with other Romanian children. $35 \%$ think that Roma people and Romanians should not live in the same neighbourhoods (CNCD August 2009).

Discrimination is also a current issue in the Romanian schools. Academic staff often have a negative attitude towards Roma children. When asked, in a recent study on Romanian teachers, if they see differences between Roma children and Romanian children, a teacher from Maramures responded: "[...] they [Roma children] do not have the capacity for long term focus, they do not have respect towards the class or school rules. There are indeed Romanian children who have the same problems, but the number of Roma children is definitely higher". The same teacher added that "Roma students are students like any others" (Duminică and Ivasiuc 2010, p. 112). As the authors of this report noted, "although at discourse level the non-discrimination principle is "preached", this does not imply giving up on negative stereotypes or putting into place non-discrimination principles." 


\subsection{National and International Policies for Access to Education of Roma People}

Recent history shows several government at initiatives for the social integration of Roma people. The first integration strategy for Roma people was launched in 2001 by the Ministry of Public Information, under the name "The strategy of the Romanian Government for improving the situation of Roma people". 3 Although issued by only one ministry and highlighting responsibilities of other ministries in some sections, the ten-year strategy set seven general objectives for preventing and eliminating discrimination, stimulating the implication of Roma people in the social life and providing equal opportunities for a better quality of life (Ministry of Public Information 2001, p. 4). A brief analysis of the strategy shows a lack of sociological or statistical research behind it, as well as vaguely/poorly defined instruments and objectives-(e.g. "providing special budgeted places for Roma people"-an instrument-was included in the education objectives) (Ministry of Public Information 2001, p. 8). Moreover, some of the proposed measures are general, without an overall vision for the support actions. Though education was one area for strategic implementation, the strategy contains ambiguous formulation especially in the education section, such as "analyzing the possibility to encourage units of primary and secondary school for Roma people" (idem, p.8), a measure that would encourage separation and segregation.

In the first national strategy adopted in 2001, the Romanian Government adopted a policy of allocating a specific budget for the Roma young people, to be used to cover the cost of "reserved places" at secondary schools and universities, and of developing appropriate instruments for their distribution. Only one progress report for the policy exists, from the first year of implementation of the Strategy. This noted the establishment of a department for education in a minority language within the Ministry of Education, along with the development of a number of programs aimed to facilitate access to education for Roma children. Since 2009 there has been no subsequent impact analysis of these study grants on the access to higher education of the young Roma people. However, several measures highlighted in the action plan have never been implemented, such as: providing a free meal per day for Roma children going to school; involving the Roma children parents in the educational process by two parent-teacher meetings per month; organizing complementary courses for Roma children to help them bridge the gaps in their education.

A subsequent national strategy for Roma people integration was elaborated ten years later, in 2012..$^{4}$ The strategy is mostly based on the "Risks and social

\footnotetext{
${ }^{3}$ Governmental Decision no. 430/2001 regarding the Strategy for improving the living standard for Roma people (available in Romanian at the following link: http://www.mmuncii.ro/pub/ imagemanager/images/file/Legislatie/HOTARARI-DE-GUVERN/HG430-2001.pdf; last accessed: September 2014.

${ }^{4}$ Published in the Official Gazette no 6/12 January 2012.
} 
inequities in Romania" research report (Preda 2009), which was produced by a social studies research team at the University of Bucharest. The 2012 strategy was an improvement on the 2001 strategy in several respects: it was issued jointly by several ministries rather than a single one, it was supported by several research reports published in the previous years, it defined negative social phenomena as exclusion and segregation as being barriers to the objective of Roma people social inclusion, and it differentiated more clearly between objectives, priorities and actions while introducing desirable clearer set of results and indicators.

\section{Methodology}

The methodology used for this study consists of document analysis and six case studies performed in six Romanian universities. Documents analysed included official government documents and strategies, sociological reports published in the previous years, as well as statistical data from Romanian universities. In order to explain the relationship between concepts and organize the existing data, the authors used a concept map that explains the conditions of access and success in education for Roma people. The case study data was collected during study visits at six public Romanian universities of various profiles and geographical positioning. Each study visit included meetings with students, the Rector, Vice-Rectors, Deans and Vice-Deans (group discussion), General Administrative Directors, secretaries, admission responsible, coordinator of Orientation Center and decision making university representatives.

A final source of data is the results of an online questionnaire applied in the same universities, aimed at identifying perceptions of how Roma people fit among senior faculty members (Deans and Vice-Deans). The online questionnaire included 16 questions, using ordinal, symmetrical five-point scales to gauge strength of opinions. The questions tested opinions and knowledge of respondents regarding the criteria for defining a vulnerable group, views on bariers to success for different disadvantaged categories in higher education and their views on the likely efficacy of different possible support measures for these groups. 52 vice-deans in the universities which were visited responded to the survey; of these 25 were male and 27 were female. The age distribution of the respondents was: 21 under the age of 45 , 21 between 45 and 55 years of age and 10 over the age of 55. Over half the sample (33 respondents) had between 15-25 years of experience in higher education, seven respondents had over 25 years of experience, while only 12 respondents had less than 15 years of experience. Since the questionnaire did not address only the topic of reserved places for Roma people, only a part of data will be cited in this paper, in order to complete the results of the interviews. 


\section{Results}

\subsection{Influence Factors on the Participation of Roma People to Education}

In a strategic document issued by a governmental body, (European Commission 2007, p. 52), exclusion is defined as the incapacity or failure of integration of a person or a group in society, on the labour market and at community level. In the same documents, "social integration" is described as the process by which a functional balance between individual and social environment is achieved, while "social inclusion" refers to the access of individuals from vulnerable groups to the subsystems accessed by the larger community (idem, p. 53). The Presidential Commission Report on the Analysis of Social and Demographic Risks (Preda 2009, p. 226) mentions two specific features of social exclusion in case of Roma people: discrimination (the social stigma together with the label of "gypsy") and the exclusion from mainstream societal activities.

\subsubsection{Participation of Roma People in Education}

Starting in 1990, the Ministry of National Education developed several policy measures in order to increase Roma access to secondary and tertiary education. One of the most important measures set in place by the Ministry was to provide special "reserved places" for Roma students for admission to secondary schools and universities. A World Bank and Ministry of Education, Research and Youth study (2008) indicates that less than $1 \%$ of the Roma population graduates from higher education. According to the Ministry of National Education data for secondary education, the number of Roma students admitted in Romanian high schools increased by $44.2 \%$ from 2009/2010 to 2011/2012. Despite this increase at secondary education level, Table 1 shows that the number of places reserved for Roma students at the secondary level is still quite far from being fully used, with only $41 \%$ of such places having been used. (UEFISCDI 2013, p. 34).

The situation of Roma children in schools highlights a very complex and worrying picture. The access of Roma people to preschools is limited. Only $61 \%$ were registered and finally, only $20 \%$ had access to preschools in 2000-2001. Among 15-18 year olds, only $36 \%$ of Roma were enrolled in school, compared to $79 \%$ of the overall population (EUMAP 2007).

On average, Roma children spend only 6.8 years in formal education, compared to an average of 11.2 years for the general Romanian children population. Roma girls are overrepresented among children unenrolled in schools, (39\% vs. $29 \%$ for boys) (Surdu et al. 2011, p. 29). This is because girls' enrollment in school is affected by early marriages: $10 \%$ of Roma girls have their first child between 12 15 years, and $48 \%$ between 16-18 years (Preda 2009, p. 228). Due to the homogenous nature of Roma communities, over half of Roma children learn in 
Table 1 Roma participation in secondary education, Ministry of National Education 2012

\begin{tabular}{l|l|l|l}
\hline Academic year & $2009-2010$ & $2010-2011$ & $2011-2012$ \\
\hline $\begin{array}{l}\text { Number of allocated "reserved places" for Roma } \\
\text { students in highschools }\end{array}$ & 7483 & 7675 & 7906 \\
\hline Number of Roma students admitted to high school & 2246 & 2675 & 3239 \\
\hline
\end{tabular}

schools with a predominant Roma population (Preda 2009, p. 229), and thus homogenity in practice looks a lot like segregation. Almost $60 \%$ of preschool Roma children are enrolled in a preschool with more than $50 \%$ of Roma children, while $11.7 \%$ are enrolled in all-Roma children classes. In families with at least one case of school dropout, $56.5 \%$ of children learn in segregated classes, while $9.1 \%$ learn in all-Roma classes (Surdu et al. 2011, p. 10). According to a 2010 report, Roma community schools function with scarce resources due to social stigma and lack of human and material resources. The same study also noted that a school's likelihood of possessing specialized laboratories was inversely related to the percentage of Roma children attending the school. The number of qualified academic staff at a school and the number of books it possesses per student were similarly found to have an inverse relationship with Roma enrolment (Duminică and Ivasiuc 2010, p. 69). According to another research study, Roma children studying in predominantly Roma classes have a higher risk of repeating a year compared to the Roma children in mixed classes: approximately $15 \%$ of pupils in predominantly Roma classes are illiterate, in comparison with only $4 \%$ of Roma children in mixed classes (Florea and Rughiniş 2008, p. 159; Preda 2009, p. 229).

In short, the predicament of Roma students is rather complicated, since their lack of access to education and high dropout rates are influenced by numerous independent factors, such as their social background, poverty, lack of access to education (caused by faulty infrastructure, e.g. no access roads), parents' level of education, discrimination or, in a few cases, their cultural backgrounds (e.g. patriarchal communities).

\subsubsection{The Dropout in Schools of Roma Children}

According to the 2012-2020 Romanian Government Strategy for inclusion of Romanian citizens of Roma minority, Roma people have the highest dropout rates compared to any ethnic groups. The 2002 census shows that only $21 \%$ of the Roma youth in the 15-18 age group were still enrolled in schools, (18\% for women, $24 \%$ for men). Also, approximately $80 \%$ of all unenrolled children belong to the Roma population, out of which $38 \%$ are functionally illiterate. In primary schools, the Roma enrolment rate is $64 \%$, compared to an average of $98.9 \%$ for the rest of the country (Presidential Report 2007, p. 8).

According to Duminică and Ivasiuc's (2010) report, the annual dropout rate among Roma children is $6.7 \%$. However, this figure was arrived at based on self-reporting by Roma children (enrolled or not in compulsory education); the authors suggest that the real dropout rate among Roma children may be as high as 
$9 \%$. The most important reasons for dropout include poverty (mentioned by $44 \%$ of the respondents) and repeated unsatisfactory school results such as repeating a year of school (mentioned by $16 \%$ of respondents). According to the surveys of Roma children and their parents, the results contradict the stereotype according to which Roma children dropout rates are a result of early marriages which affected only $4 \%$ of respondents. The same study- "School for everyone?"-contradicts another stereotype, namely that Roma parents are not interested in sending their children to school, this being noted in only $9 \%$ of the responses. Thus, $90 \%$ of the Roma parents have a positive attitude towards education, maintain constant contact with teachers and encourage their children to perform well in school (Duminică and Ivasiuc 2010, p. 10).

Additionally, it is worth mentioning Duminică and Ivasiuc's conclusion that "Roma children rarely go beyond secondary school education due to poverty reasons." This phenomenon is predominant in the rural area, where families do not benefit from adequate infrastructure or financial resources to send their children to an urban high school (at least 5-10 km away from their homes). The same poverty issue makes teenagers stay home and work, in order to financially support their families. However, this problem is not specific to Roma communities, but is common for the rural population in general.

One more reason why Roma children's education often ends at secondary school level is the parents' subjective balancing of the financial costs and benefits gained by having their children continue education (Duminică and Ivasiuc 2010, p. 11). Disadvantaged families find it difficult to maintain a long-term approach to education when they have difficulty meeting basic needs, making them more focused on a one day at a time approach.

Reasons behind school dropout. $57.6 \%$ of Roma parents stated that at least one of their children abandoned school and $21.1 \%$ had two children unenrolled or in situation of dropout (Surdu et al. 2011, p. 31). In the cited study (p. 32), $44.2 \%$ of the 7-11 year children were not enrolled in any form of education, while $64.6 \%$ of 12-16 year children abandoned school. The most frequent reasons for dropout are economic ones $(41.8 \%)$, absence of parents or parents' indifference to school (27\%), deficiencies of the educational system (mainly discrimination-12.5\%), illness or incapacity $(9 \%)$, early marriage $(6.6 \%$ - only girls in this category) (Surdu et al. 2011, p. 51). From the overall percentage of children who abandoned school, $47.6 \%$ repeated the year once, $38 \%$ repeated the year twice, while $12 \%$ repeated the year three times-which is the maximum limit before being definitely expelled from school. In the 12-16 year category, household work is the dropout reason for a third of respondents. The perceived "uselessness of school" was cited as a reason for dropout in $21.1 \%$ in the same age category; with this reason being more common among girls than among boys (Surdu et al. 2011, pp. 6-7).

Among reasons for school dropout cited by parents (Surdu et al. 2011, p. 59), the most common were family's economic status (49 \%), household work (27\%), employment $(20 \%)$, family tradition-i.e. that parents did not go to school $(23 \%)$ and early marriage (14\%). This situation is compounded by their described social conditions, characterized by low and inconsistent income (since their main income 


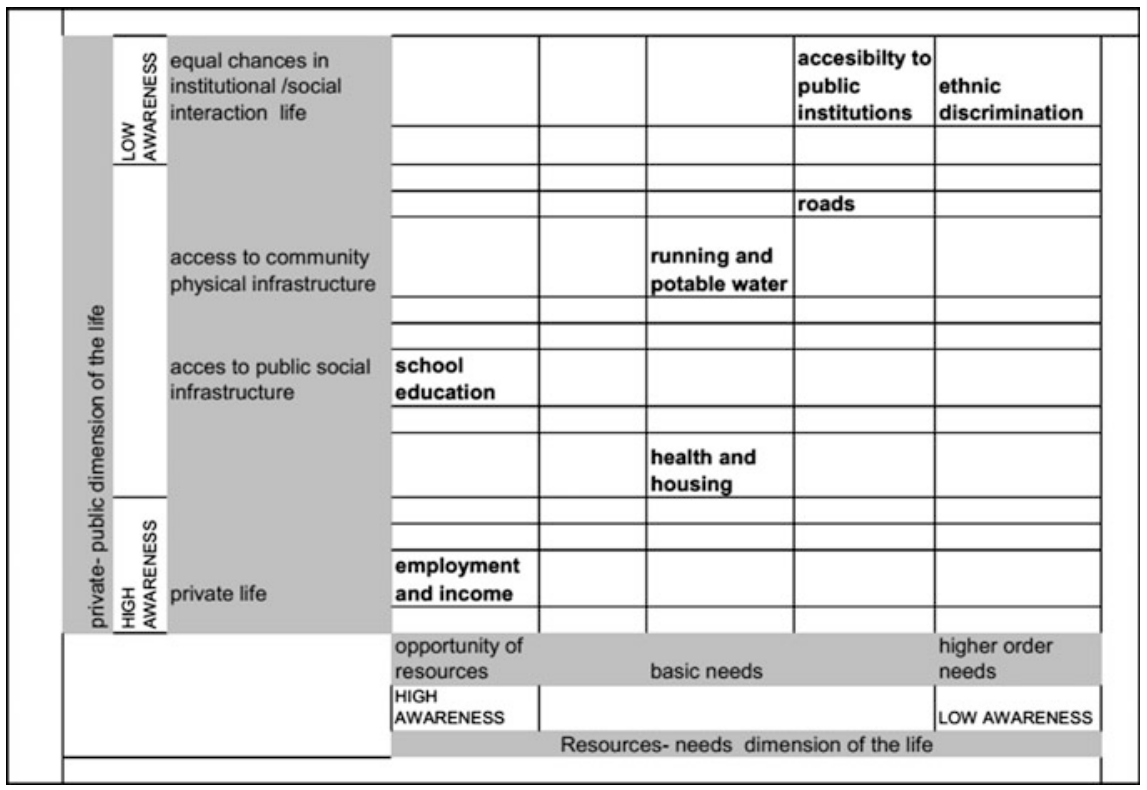

Fig. 1 The hierarchy of perceived social problems in Roma communities by resources-needs and private-public dimensions (Source Roma Social Mapping-Targeting by a Community Poverty Survey) (2005 World Bank report, available at: http://www.anr.gov.ro/docs/statistici/Roma Social_Mapping_187.pdf. Last accessed at 15 September 2014)

source are manufacturing, daily activities, agriculture and only rarely working in industries) and low access to educational resources. This is better reflected in Fig. 1.

The concept matrix built in Fig. 2 explains all the factors influencing the participation of Roma people in higher education, and which narrow the educational

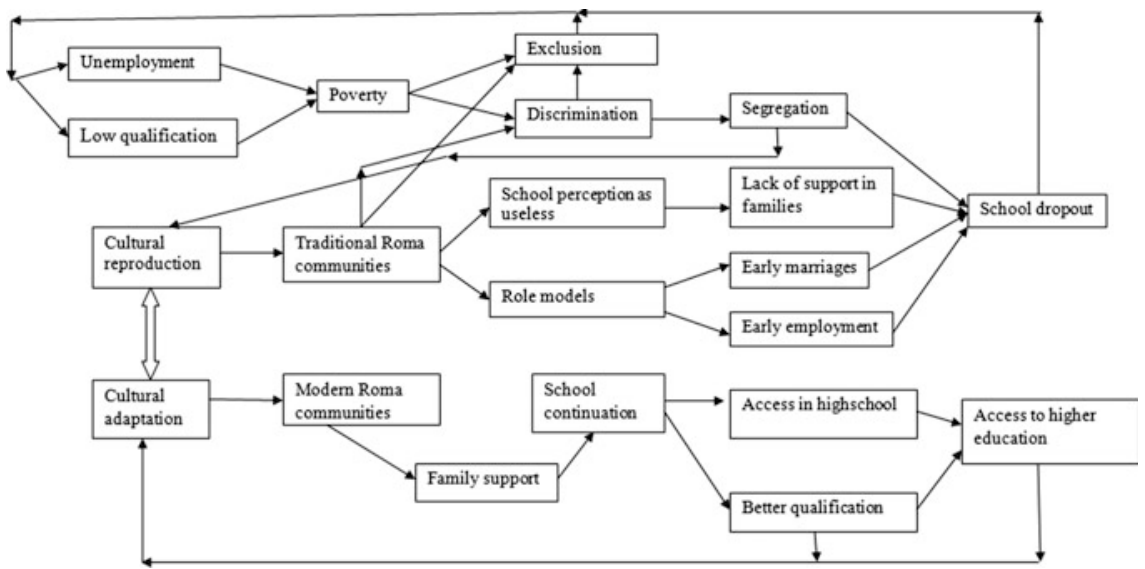

Fig. 2 Conceptual matrix of the complex factors influencing the access and success in education for Roma children 
path for most members of this ethnic category. The upper part explains the systemic circles that increase exclusion, dropout, low qualifications and poverty, while the "cultural adaptation" route might increase the chances to success and the quality of the educational path for Roma children.

\section{The Efficiency of Reserved Places for Roma People in Six Romanian Universities}

The policy of reserving places for Roma people was designed as a pilot in 19921993, by the Faculty of Sociology and Social Assistance, and was introduced as a public policy in the academic year 1999-2000. Using statistical data, focus groups and interviews with several key actors (including 175 students and graduates), Surdu and Szira (2009) inquired about the efficiency of the reserved places for Roma people in highschools and universities in the 2000-2006 period, as well as the characteristics of the educational process under these conditions. The data analysis we performed in the IEMU project will be interpreted with reference to the results of this study.

Regarding the participation of Roma students in higher education, according to the Government Decisions of 2010, 2011 and 2012, the number of stated financed places reserved for Roma evolved as shown in Table 2.

Unfortunately, no information is available regarding the percentage of these study places which were actually taken up. Also, there is no data available regarding the number of higher education Roma students who do not benefit from these reserved places. There are cases when Roma students do not apply for a reserved place, but go through admission procedures as the other students, refusing to declare their ethnicity. Our case study interviews showed that many of those Roma students did not apply for a reserved place for fear of stereotyping and discrimination against them.

Information and access procedures. Information about the reserved places, although usually not highlighted in the promotion events and materials designed and published by the universities, is usually published on their faculties' websites. Roma students indicate that the Internet, family members and friends are the most common sources of information about reserved places. Surdu and Szira (2009, p. 50) described the process of access and enrollment on a reserved place as difficult, mainly due to lack of information, bureaucracy, the last minute announcement of reserved places. The authors also concluded that ethnic NGOs played an important role in disseminating information and the decision-making

Table 2 Places for Roma students in higher education

\begin{tabular}{l|l|l|l}
\hline Academic year & $2010-2011$ & $2011-2012$ & $2012-2013$ \\
\hline Number of places for Roma students (Bachelor) & 555 & 611 & 555 \\
\hline
\end{tabular}

Source UEFISCDI, Bucharest (2013) 
process for choosing a reserved place for Roma candidates. However, our study showed a radically different situation: increased university flexibility and the places distribution procedure (although different between universities) lead to a better use of the reserved places. The Surdu and Szira study identifies no links between the university and the Roma NGOs, but our study noted an improved collaboration between these NGOs and the university administration, in some cases. On a last note, our findings did not show a direct influence of Roma NGOs over the candidates' decision, rather, this decision is usually influenced by family (who still plays a major role in supporting the student throughout his academic path).

Reasons behind accessing the reserved places. Surdu and Szira (2009, p. 82) identified the most frequently-cited reasons for accessing reserved places: the certainty of tuition free admission (41 \%), easier admission procedures (26\%), guaranteed access to certain specializations (19\%), desire to further education $(11 \%)$ and the right to benefit from these places $(9 \%)$. Our qualitative results show that the certainty of tuition free admission (stated by beneficiaries) and guaranteed access to certain specializations (indicated by some admission officers) are the main rationales behind accessing reserved places. $78 \%$ of the Roma students say they would have enrolled even in the absence of these measures (Surdu and Szira 2009, p. 82); presumably, this high percentage indicates an elevated capacity for support from their families. Our study reached the same conclusion, namely that most Roma beneficiaries of the reserved places would have enrolled in faculty even without this support form, as they benefited from good financial background and high support from their family regarding their education.

Specializations in which Roma people were enrolled on reserved places. According to Surdu and Szira (2009, p. 11), during the period 2000-2006, approximately 10,300 students enrolled in secondary and vocational education on specially reserved places for Roma people, and approximately 1420 students benefitted of similar places in universities. Between 2000 and 2006, the number of students admitted on the reserved places in secondary education increased fivefold, while in higher education institutions the increase was fourfold. The preferred fields of studies for Roma people accessing reserved places were Humanities (35\%), Arts (19\%), Economic Sciences (18\%) and Law/Administration (12\%), Engineering (9\%), Applied Sciences (4\%), and Medicine/Pharmacy (3\%). During the six years analysed, only two thirds of the reserved places for Roma students had been occupied (idem).

The policy perception. In the study by Surdu and Szira (2009, pp. 48-49) there is a clear distinction between the positive perception of the policy for the Roma NGOs and beneficiaries on one side, and the negative perception of the policy by secondary school officials (i.e. some of the key actors responsible for implementing the policy). Roma NGOs and beneficiaries perceived the policy as leading to admission advantages, support measures and an opportunity to change mentalities. School officials on the other hand perceived the reserved places as an inefficient and a discriminatory measure, one which was in just to non-Roma students. The policy as a whole was tolerated, rather than actively supported. Our study found a similar divergence of opinions. Additionally, our focus group work revealed that many 
Romanian students considered the policy as being a discriminatory measure and unfair to the rest of students: "I do not approve of this policy. It is unfair for the rest of the students. Inclusion policies should be applied in early education, not at university level." (President of the students' association, study visit no. 1). "Roma people are not a vulnerable group. They should try to fit, enter in society by their own endeavours. A better definition of vulnerable groups is needed (female student, study visit no. 1)". "Roma people should have the same admission procedures as the rest of the candidates, there should not be differences. (male student, study visit no 4)". "Why do they enter with a 5.00 grade causing some Romanian students to lose the budgeted place with a 9.00 grade in the admission examt?" (Vice-Rector, study visit no. 1). "Do they know to speak Romanian correctly, at least?" (Associate Professor, study visit no. 6).

Our interviews tended to show that Roma people are not perceived as poor, discriminated or marginalized within universities (see Fig. 3). While some students agree with the policy (study visit no. 5), they remain sceptical about the Roma students' interest in advanced studies and their capacity to meet the university requirements.

Our case-study site visits, revealed a number of common attitudes among secretaries and students: lack of knowledge and understanding of the notion of vulnerable groups, lack of acceptance that some problems could substantiate affirmative policies as reserved places, lack of support measures and, in regard to the investigated policy, either reluctancy or unbiased attitude. Reserved places were not always promoted by universities educational offer; rather, the information was accessed by NGOs and interested candidates, especially via internet or friends/family/acquittance who had access to correct information.

Support during academic studies. According to Surdu and Szira (2009, p. 89), $32 \%$ of their respondents received a social allowance, $14 \%$ a study allowance and

Fig. 3 Intensity of support measures required by different categories of candidates, on a scale from 1 to 5

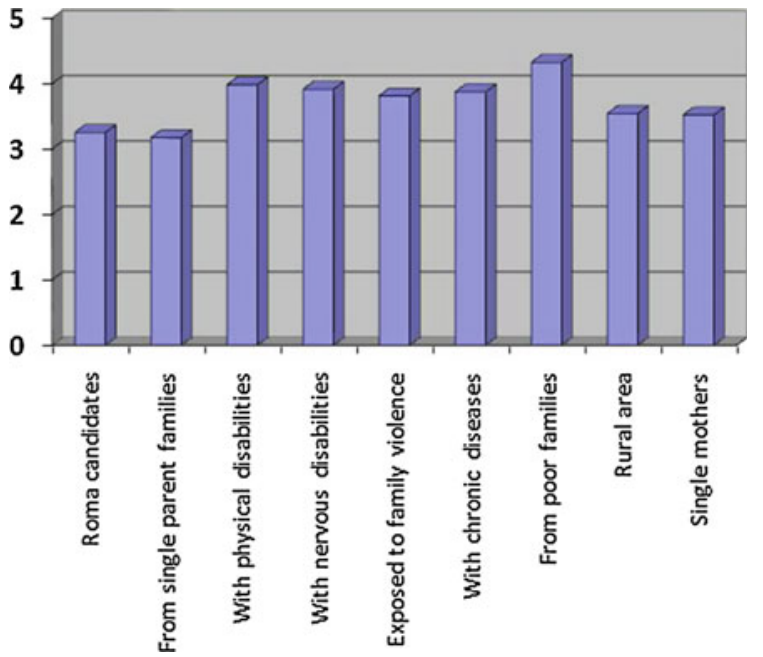


$5 \%$ a merit allowance. In our study, the qualitative results do not provide information on this topic. Our interviews indicate that the beneficiaries are informed about the possibility to obtain a social allowance, but less informed by the possibility to obtain other types of support (such as psychological and orientation counseling). The availability of other support instruments, such as university campus accommodation or supplementary allowances varied from one university to another.

Performance in higher education. According to the study of Surdu and Szira (2009), $80 \%$ of Roma students in reserved places assessed themselves as being in the top half of their class in term of academic achievements. The qualitative data in our study showed that Roma students have a normal attitude towards learning, have no records of lack of discipline, are not registered as sources of conflicts, and a majority of them observed faculty regulations.

Relationships with colleagues and teachers. In the Surdu and Szira study, $86 \%$ of the Roma students had more Romanian friends than Roma friends, and $93 \%$ reported a good relationship with colleagues (Surdu and Szira 2009, p. 99). However, they noted differences among universities in terms of making reserved places public knowledge. Our results indicate that most universities do not make public the names of candidates enrolled on reserved places, which makes integration of the Roma students easier. As far as the relationship with teachers is concerned, tensions between students and teachers have been reported at the high school level, not at university level.

Obstacles to completion. Surdu and Szira (2009, pp. 84-85) identified several obstacles in completing a cycle of education. The general factors referred to the perception of education in society (as bringing poor social and not many material benefits), preconceptions and poverty (poor family resources). The specific limitation factors referred to the lack of information about the reserved places, reluctancy in stating Roma origin, the lack of family support, the fear of losing community values. Other identified reasons for dropout (Surdu and Szira 2009, pp. 92-93) include: low access to scholarships (caused by either bureaucracy or lack of IDs), lack of moral support from teachers and counselors, pressure exerted by colleagues, early marriages. In our study, the results show better results with respect to candidates' information level, a lack of pressure by colleagues, and also a better access to information regarding allowances. The other factors are more or less the same, especially in terms of alternative occupation (marriage, employment), but in this respect Roma are a little different from other Romanian students. Our interviews with the university representatives also indicated the lack of perseverance as a perceived limitation (study visit no. 5).

Compared to the study by Surdu and Szira, the results of our six case-study sites revealed two other findings of note. The first one refers to the socio-economic level of the Roma students enrolled on reserved places: they belong to the middle and upper class of this ethnicity and fit into the "culturally adapted" Roma people category (there are no cultural and language differences from the Romanian majority). In only one case could an admission officer recall traditional Roma students coming to enroll on reserved places. Elsewhere, the Roma candidates and students have been described as people who are not different from the other 
students, either in status or in behavior. In our interviews with the beneficiaries of the budgeted places (six interviews), the participants came from middle class or wealthy families, with a small number of children, and whose parents had completed at least secondary education. Only one of the six interviewed students encountered financial difficulties and dropped out of university due to being in a situation of working full-time in order to financially support his family. The others described their context as being the same as for Romanian children, and the cultural background of their family as having no connection with the Roma culture. Only one out of the six interviewed beneficiaries experienced discriminatory situations in highschool and felt neglected. The six interviewees considered the reluctance in declaring Roma origins and the fear of labelling as important reasons for Roma candidates not accessing the reserved places. This suggests that only the more educated and wealthy Roma people have real access to the reserved places. The majority are still not able to reach tertiary education level, given the multiple barriers described in the first part of the paper.

The second finding is with respect to the lack of understanding of the particular difficulties experienced by students from vulnerable groups during their evolution. Universities situated in less developed areas (two out of the six analyzed institutions) had put in place a set of institutional measures addressing students from poor families, but this was the only vulnerable group taken into consideration. Only one out of the six universities had a coherent policy for vulnerable groups as a whole (including, for example, students with disabilities). The other five universities can be described as having a reactive approach. Policies in line with the legislative national framework are recognized and respected, but responsible actors within universities are unwilling to develop internal instruments that go beyond these minimum standards and implement these policies in an unbiased manner. In the specific case of Roma people, both students and some university representatives were against the policy of reserved places and defined lack of discrimination as "treating all students equally" ("we do not facilitate individual problems resolution, all students are being treated equally: if they have a problem, they should speak to the Dean"-admission responsible, study visit no. 3). Thus, university representatives frequently ignore the potential complex difficulties of students coming from vulnerable groups (including Roma people). In five of six universities, problems are solved on a case-by-case basis, merely responding to particular requests instead of a coherent and integrated approach by means of internal regulations.

This finding was confirmed by the results of the online survey. Respondents on the whole did not perceive students from single-parent families or children with parents working abroad as being disadvantaged. The most frequently agreed-with categories in terms of vulnerability were foster children, people with disabilities and children from very poor families. Respondents also considered that some vulnerable categories would need support measures (see Fig. 3). From ten potentially vulnerable categories which could benefit from support measures in order to enroll to the university, Roma people were only listed at number nine, ahead only of students from single-parent families (which were not considered as a vulnerable group by most respondents). 
Fig. 4 Chances of successfully completing the academic formation, on a scale from 1 (minimum) to 5 (maximum)

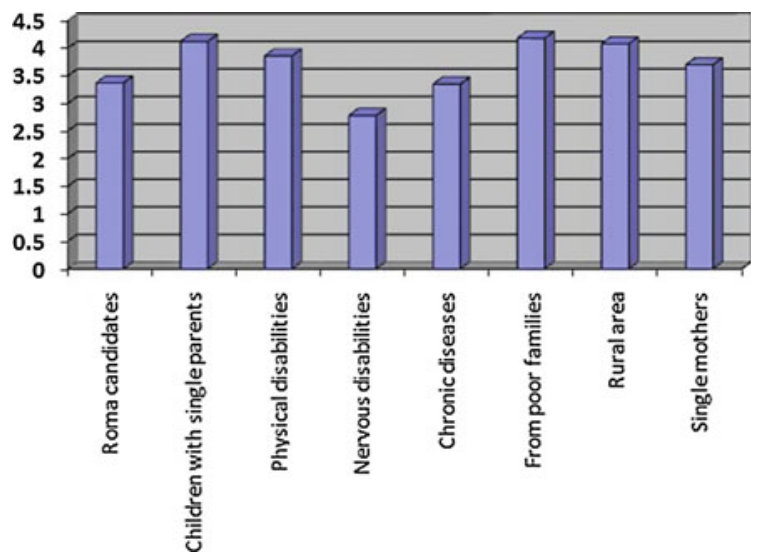

According to the survey respondents, although support measures are necessary for several vulnerable categories, each of these groups is seen as having quite different chances of completing their academic formation and achieving success in their social and professional lives (Fig. 4). Roma students, students with chronic diseases and students with mental health problems are considered by respondents as having the least chance of completing studies and successfully integrate in the professional environment.

In the respondents' opinion, the first three factors that limit the access and success of Roma people to the academic environment are: early dropout, lack of family support and lack of good examples (see Fig. 5).

The answers to the question in Fig. 5 show some degree of stereotyping: the limitations for Roma are seen as being related to their cultural background, with poverty or discrimination being less-frequently mentioned.

Fig. 5 Intensity of factors limiting access of Roma people to higher education

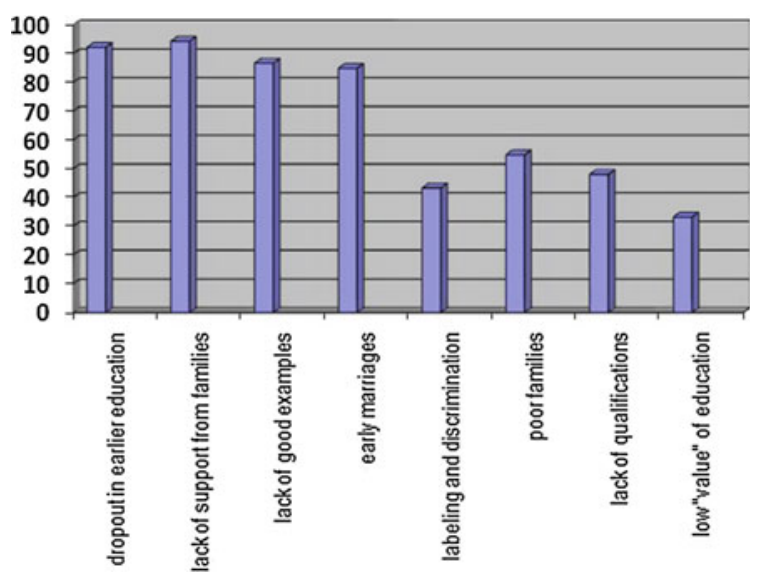


The integration of these quantitative and qualitative results highlights a lack of understanding of specific Roma people's problems at university representatives' level. An additional finding shows the formal acceptance of the reserved places policy, complemented by mistrust in its efficiency. Deeply rooted stereotypes of Roma persist among teachers and academic staff. Under these conditions, where potential partners and official actors are reluctant to implement the appropriate measures, it is difficult to ensure the implementation success of a policy.

\section{Limitations of Research}

The study visits covered six universities of different profiles and geographical positioning. Some universities did not facilitate face-to-face interviews with the beneficiaries of the reserved places, and the only data available came from teachers and administrative staff. In addition, the reserved places in the six universities represent only a small fraction of the total number of students, and universities were sometimes unable to provide us with individualized academic data pertinent to this group (rectors, vice-rectors, and members of the Senate mentioned that the administration does not specifically monitor these students in order to be able to provide statistical data about their integration and performance once admitted). Another limit is the potential bias of answers in interviews with various university actors, many of whom showed a clear desire to present their university in a positive light. Finally, there is the small number of responses to the online questionnaire (52 answers) which limit the generalizability of the findings.

\section{Conclusions and Recommendations}

Compared to earlier studies, our results show something of an improvement in the situation for Roma with respect to their general information level, the distribution flexibility of reserved places among specializations, as well as an increased transparency of admission procedures. Furthermore, data from our case-study site visits seemed to indicate an improved communication with the Roma NGOs, and a greater autonomy of individual candidates while making the decision to enroll in their preferred specialization. On the negative side, there are still reserved places unoccupied. Due to complex limitations, the reserved places in higher education are used by a small category of middle and upper Roma class, culturally homogeneous with the other Romanian students. Finally, teachers, administrative staff or Romanian students still manifest a lack of interest towards problems of disadvantaged and vulnerable groups, including Roma students.

On the long term, several recommendations can be formulated. The issue of Roma people access to higher education needs to be further investigated in light of the limitations of access at lower cycles (primary and secondary education). 
Supplementary support mechanisms for Roma students coming from poor or traditional background need to be developed.

A secondary direction addresses the public acceptance for support mechanisms and policies designed for disadvantaged and vulnerable groups. In order to raise awareness and improve public perception of specific problems encountered by these groups, coherent information and communication campaigns should be implemented. At university level, proactive adoption of best-practice examples should be rewarded in order to motivate a change in attitude towards support of vulnerable groups. In keeping with the spirit of the Bologna Process, universities need to eliminate the current reactive and passive attitude towards disadvantaged students' needs and begin addressing them in a more systematic fashion.

Open Access This chapter is distributed under the terms of the Creative Commons Attribution Noncommercial License, which permits any noncommercial use, distribution, and reproduction in any medium, provided the original author(s) and source are credited.

\section{References}

Andreescu, G. (2005). Schimbare în harta etnică a României (A Change in the Romanian Ethnic Map). Cluj: Ethnocultural Diversity Resource Center.

Bennett, J. (2010). Project Inclusion of Roma people in early children's development services (research report) Foundation for an Open Society. Retrieved from http://medlive.hotnews.ro/ wp-content/uploads/2010/12/Raportul-Na\%C5\%A3ional-IRSDTC-pentru-Rom\%C3\%A2nia_ rezumat.pdf

CNCD, Consiliul National pentru Combaterea Discriminarii (August 2009). Fenomenele discriminării în România-perceptie şi atitudini. (Discrimination phenomena in Romaniaperception and attitudes).

Duminică, G., \& Ivasiuc, A. (2010). O școală pentru toți? Accesul copiilor romi la o educație de calitate. Raport de cercetare. (A school for everyone? Access of Roma children to a quality education. Research report). Retrieved from http://www.unicef.ro/wp-content/uploads/o_ scoala_pt_toti.pdf

EU Agency for Fundamental Rights. (2009). EU-Midis. European Minorities and Discrimination Survey. Retrieved from http://fra.europa.eu/sites/default/files/fra_uploads/413-EU-MIDIS_ ROMA_EN.pdf

EUMAP. (2007). Accesul egal la învăţământ de calitate pentru romii din România. (Equal access to quality education for Roma from Romania). Retrieved from http://www.anr.gov.ro/docs/ Politici/Acces\%20egal\%20la\%20educatia\%20pentru\%20romi.pdf

European Commision (2007). Politici de incluziune socială pentru grupurile vulnerabile. Creşterea accesului pe piaţa muncii (Politics of social inclusion for vulnerable groups. The increase of access on labour market) http://www.academia.edu/3839998/7_Politici_de_ incluziune_RO_p_ro

Florea, I, \& Rughiniş, C. (2008). Vino mai aproape. Incluziunea şi excluziunea romilor în societatea românească de azi (Come closer. The social inclusion and the social exclusion of Roma people in the Romanian society from nowadays), Human Dynamics, Bucharest.

Ministry of Public Information. (2001). Strategia Guvernului României de Îmbunătățire a Situației Romilor. (The Strategy of Romanian Government to improve the Roma People Situation). Retrieved from http://www4.pmb.ro/wwwt/pactivi/Doc\%20legislatie/strategiiromi.pdf 
Preda, M. (2009). Riscuri și inechități sociale în România [Risks and social inequalities in Romania].

Presidential Report. (2007). Raportul Comisiei Prezidenţiale pentru analiza și elaborarea politicilor în domeniul educației și cercetării (Romania of education, Romania of research-Report of the Pressidential Commission for analysis and construction of politics in education and research) România educaţiei, România cercetării. Bucharest.

Surdu, M., \& Szira, J. (2009). Analysis of the impact of affirmative action for Roma in high schools, vocational schools and universities. Retrieved from http://www.romaeducationfund. hu/sites/default/files/publications/gallup_romania_english.pdf

Surdu, L., Vincze, E., \& Wamsiedel, M. (2011). Participare, absenteism școlar și experiența discriminării în cazul romilor din România (Participation, absence in school and the discrimination experience), Romani Criss. Retrieved from http://www.unicef.ro/wp-content/ uploads/ghid_absenteism.pdf

UEFISCDI, Unitatea Executiva pentru Finantarea Invatamantului Superior, a Cercetarii, Dezvoltarii si Inovarii (2013). Echitate în învățământul superior din România (Equity in the Romanian higher education system). Retrieved from http://www.politici-edu.ro/wp-content/ uploads/2013/10/Equity-in-the-Romanian-Higher-Education-System_policy-document.pdf 